\title{
Phase II AIDS Malignancy Consortium (AMC) trial of imatinib in AIDS-associated Kaposi's sarcoma (KS)
}

\author{
Henry B Koon ${ }^{*}$, Kord Honda ${ }^{2}$, Jeannette Y Lee ${ }^{3}$, Susan M Christner ${ }^{4}$, Merrill J Egorin ${ }^{4}$, Ariela Noy ${ }^{5}$ \\ From $12^{\text {th }}$ International Conference on Malignancies in AIDS and Other Acquired Immunodeficiencies \\ (ICMAOI) \\ Bethesda, MD, USA. 26-27 April, 2010
}

\section{Background}

KS is a disease of multifocal vascular proliferation that requires infection with the KS herpes virus (KSHV/ HHV-8). Activation of the c-kit and platelet derived growth factor (PDGF) receptors by autocrine and paracrine mechanisms follows KSHV infection of endothelial cells. Partial KS regression in 5/10 patients was observed in a pilot study using the c-kit/PDGF-R inhibitor imatinib (Novartis Pharmaceuticals), and 3/4 biopsies showed PDGF inhibition, suggesting this agent has activity in AIDS-related KS.

\section{Methods}

The primary objective was to estimate the response rate of KS to imatinib in AIDS-related KS. Secondary objectives included investigation of predictors of response and imatinib pharmacokinetics in patients on cART. Patients were treated with imatinib $400 \mathrm{mg} /$ day orally for up to 12 months with the option to dose escalate to $600 \mathrm{mg} /$ day at 3 months if disease was stable. Plasma concentrations of CCL5 (RANTES), IFN $\gamma$, IL-6, and FGF- $\beta$ at baseline, day 8 , and day 28 were measured using the Mesoscale platform to assess the utility of these growth factors as biomarkers.

\section{Results}

Thirty patients were treated at 12 AMC sites. Median CD4 count was 263 (19-819). 79\% had undetectable HIV RNA. Ten (33.3\%) showed partial response, 6 (20\%) had stable disease, and 7 (23.3\%) showed KS progression by modifed AIDS Clinical Trial Group response criteria. Treatment was well tolerated. Nine patients completed 52 weeks of imatinib and the median

\footnotetext{
*Correspondence: henry.koon@uhhospitals.org

${ }^{1}$ Ireland Cancer Center, Case Western Reserve University, Cleveland, OH, USA Full list of author information is available at the end of the article
}

treatment duration was 22.5 weeks $(0.3-52.7)$. Only 5 patients $(16.7 \%)$ discontinued therapy due to adverse events including grade 3 hypophosphatemia (2), allergic reaction (1), cellulitis (1), depression (1), and grade 4 elevation of CK (1). Pharmacokinetic analysis of the AUC ratios (using day 1 and 15 sampling) demonstrated that actual imatinib AUC levels were significantly higher than predicted $(\mathrm{P}=0.036)$, but there was no difference between actual and predicted AUC for the active metabolite $(\mathrm{P}=0.441)$, suggesting the antiretroviral regimens influenced imatinib metabolism. While baseline levels of CCL5 and IFN $\gamma$ and changes in the levels of IL- 6 and FGF-b correlated with response in our pilot study, none of these growth factors predicted response in this larger study.

\section{Conclusion}

Imatinib has activity in AIDS-related Kaposi's sarcoma. The potential interactions with antiretroviral drugs did not correlate with increased toxicity. Thirty percent of patients showed long-term clinical benefit and remained on imatinib for the entire year. These results suggest this regimen is well tolerated and may be an alternative to cytotoxic chemotherapy for some patients with AIDS-related KS.

\section{Acknowledgements \\ This work was supported by UO1 CA121947, R21 CA108251, and Novartis Pharmaceuticals. \\ This article has been published as part of Infectious Agents and Cancer Volume 5 Supplement 1, 2010: Proceedings of the $12^{\text {th }}$ International Conference on Malignancies in AIDS and Other Acquired Immunodeficiencies (ICMAOI). The full contents of the supplement are available online at http://www.biomedcentral.com/1750-9378/5?issue=S1.}

\section{Author details}

${ }^{1}$ Ireland Cancer Center, Case Western Reserve University, Cleveland, OH, USA. ${ }^{2}$ Department of Dermatology, University Hospitals, Cleveland, OH, USA.

${ }^{3}$ Department of Biostatistics, University of Arkansas Medical Sciences, Little 
Rock, AR, USA. ${ }^{4}$ Departments of Medicine and Pharmacology, University of Pittsburgh Cancer Institute, Pittsburgh, PA, USA. ${ }^{5}$ Department of Medicine, Memorial Sloan-Kettering Cancer Center, New York, NY, USA.

Published: 11 October 2010

doi:10.1186/1750-9378-5-S1-A61

Cite this article as: Koon et al:: Phase II AIDS Malignancy Consortium

(AMC) trial of imatinib in AIDS-associated Kaposi's sarcoma (KS). Infectious

Agents and Cancer 2010 5(Suppl 1):A61.

Submit your next manuscript to BioMed Central and take full advantage of:

- Convenient online submission

- Thorough peer review

- No space constraints or color figure charges

- Immediate publication on acceptance

- Inclusion in PubMed, CAS, Scopus and Google Scholar

- Research which is freely available for redistribution

Submit your manuscript at www.biomedcentral.com/submit 